\title{
International Associate Editors Appointed to Journal of Materials Research
}

MRS President Bob Chang and JMR Editor in Chief Walter Brown have announced the appointment of Werner Lutze and Shigeyuki Sömiya as the first Associate Editors of Joumal of Materials Research. Lutze will be responsible for solicitation, acquisitions and review of JMR manuscripts in Europe and Sömiya will handle manuscripts in Japan.

"I am pleased that Prof. Sómiya and Dr. Lutze have accepted the challenge to facilitate manuscript acquisition, review and publication of important international materials research," said Brown. "JMR has grown very rapidly over the past four years. Their work will not only enable JMR to broaden its coverage of the international field, but also to publish research results as rapidly as possible."

Lutze, head of the Reactor Chemistry and Ceramics Materials Research Group at Hahn-Meitner-Institut in Berlin, will join Kernforschungszentrum Karlsruhe in January 1990 as head of a materials research group and will lecture at the Universität Karlsruhe. Lutze received his $\mathrm{PhD}$ in chemistry from the Technische Universität Berlin. His research interests include properties and structure of inorganic ion exchangers, glass and glass ceramics, fusion reactor blanket materials, and radioactive waste management. He was organizer of both the fifth and twelfth in the series of MRS International Symposia on the Scientific Basis for Nuclear Waste Management and has been a Principal Editor of JMR since 1986.

Sömiya is professor emeritus, Tokyo Institute of Technology and professor at the Teikyo University for the Nishi Tokyo University, where his research interests span

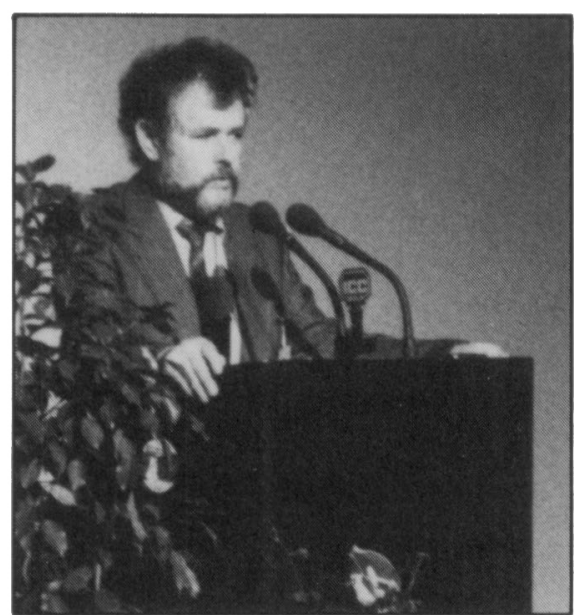

Werner Lutze

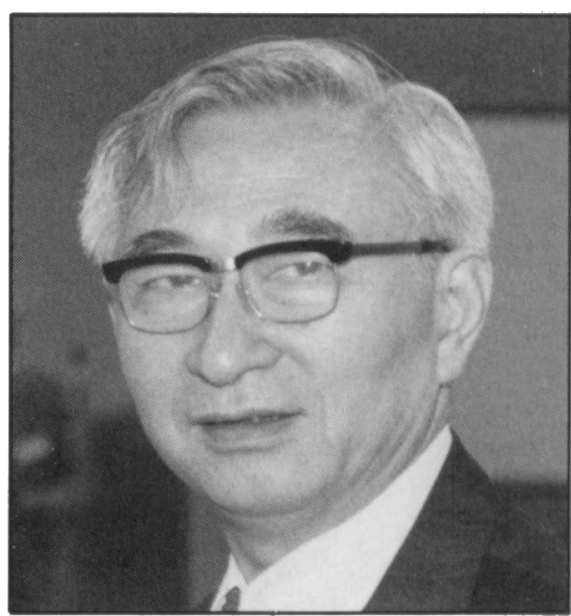

Shigeyuki Sómiya advanced ceramics. Previously a JMR Principal Editor, Sömiya has been active in a variety of MRS activities for many years. He most recently served as meeting chair, with M. Doyama and Bob Chang, for the highly successful MRS International Meeting on Advanced Materials held in Tokyo in 1988. He has been involved in the development of the International Material Research Committee, which is to be inaugurated during the 1989 MRS Fall Meeting in Boston. Sömiya was also instrumental in helping to establish the new Advanced Materials Science and Engineering Society in Japan, for which he is currently vice president.

Noting that in 1990 JMR will begin publication monthly, Bob Chang emphasized,
"There's a lot of exciting research work going on in Europe and Japan, as well as elsewhere on the international front, and with the dedication of Walter Brown, Shigeyuki Sōmiya, Werner Lutze, and the Board of Principal Editors, Joumal of Materials $R e-$ search will continue to be the key reference in the area of interdisciplinary materials advances."

Prof. Sōmiya can be reached at the Nishi Tokyo University, 37-19 Seijo, Setagaya, Tokyo 157, Japan; telephone (3) 417-2866; fax (3) 415-6619.

Until January 1990, Dr. Lutze can be reached at Hahn-Meitner-Institut, Postfach 3901 28, D-1000 Berlin 30, West Germany; telephone (030) 8009-1; fax (030) 8009-2999.

\section{If your library doesn't subscribe to Journal of Materials Research, don't you think it should?}

\author{
Your colleagues will beṇefit from JMR's \\ - new monthly publication schedule \\ - distinguished editorial leadership \\ Walter L. Brown, Editor in Chief \\ Shigeyuki Sōmiya, Assoc. Editor \\ (Japan); \\ Werner L. Lutze, Assoc. Editor \\ (Europe)
}

\author{
- interdisciplinary emphasis \\ - accessibility-JMR is referenced in Chem \\ Abstracts, Current Physics Index, Science \\ Citation Index, Metals Abstracts, INSPEC, \\ and many other key bibliographic systems.
}

...and You will benefit by always having a "backup" in case you loan out your copy of JMR.

Tell your librarian about Journal of Materials Research! 